\title{
REVIEW OF THE SURVEY'S ACTIVITIES IN 1973
}

\author{
K. Ellitsgaard-Rasmussen
}

The Geological Survey of Greenland (GGU) is the official government department of the Ministry for Greenland responsible for scientific and practical investigations of all geological matters relating to Greenland. In Greenland the main activities in 1973 were geological mapping, ground and airborne geophysical work, glaciological and hydrological projects, as well as visiting economic sites for the Ministry for Greenland leading to advice on affairs concerning concession rights.

Interest in the economic potential of Greenland's bedrock has remained high. The Survey has dealt with matters concerning the radioactive resources of Greenland together with environmental and pollution aspects in connection with the exploitation of resources. Accordingly the chemistry laboratory has been expanded both in personnel and instrumentation resulting in a marked increase in analytical capacity. Additional departments dealing with ore geology, technical geology and geochemistry have been planned. In preparation for the mapping of the large areas of sedimentary rocks in North Greenland, the Survey employed in 1973 its first full-time palaeontologist.

It was not possible to continue the marine geophysical programme started in 1973 but marine and airborne geophysical surveys form an important part of planned future work. Increasing attention will be paid to the continental shelf of Greenland, an area of approximately $600000 \mathrm{~km}^{2}$, particularly in respect of the hydrocarbon potential.

\section{Personnel}

The number of permanent staff employed by GGU increased in 1973 to 88 . Scientific personnel numbered 26 geologists and 3 chemists, the remainder being laboratory, technical and administrative staff. As usual, this figure was substantially increased during the summer period of field work in Greenland; 25 additional scientific personnel were employed.

Out of a total of 93 expedition members travelling to Greenland, 40 were geologists and 2 senior students. Supporting staff included skippers, boat hands, pilots, mechanics, base-camp personnel and field assistants. The last named were mainly geology students from Danish universities. These were joined in Greenland by locally hired labour, mainly Greenlanders, who acted as assistants and crew members on boats. 


\section{Field operations}

The main field operations in Greenland took place during June to September and were concentrated in the six main regions shown in fig. 1. Field parties were flown from Copenhagen by commercial airline to airports at Søndre Strømfjord and Narssarssuaq in West and South Greenland, from where travel continued to field and base-camps by helicopter or ship. One party travelled via Iceland and continued to Mesters Vig, East Greenland, by chartered aircraft.

Air support was by Bell helicopters owned by GGU and Heliswiss A/G Bern, a Britten-Norman Islander from Vængir Airtransport Co., Iceland, and a Turbo Hawk Commander from Ehrenström Flyg AB, Stockholm.* Surface transport was by GGU ships, outboard motor-boats and in selected areas by jeeps and ruggedterrain motor-cycles.

Apart from the main summer activities visits to Greenland at other times of the year have been made by GGU personnel in an advisory capacity to the Ministry for Greenland in connection with mining activities, in preparation for summer field work and to a glaciological excursion.

\section{Projects}

Field projects undertaken in 1973 can be assigned to seven main groups concerned with,

(a) geological mapping aimed at 1:100 000 map sheets,

(b) geological mapping at various scales,

(c) Cenozoic investigations,

(d) geophysical investigations,

(e) geochemical investigations,

(f) specialised projects,

(g) economic investigations.

(a) Basic geological mapping was carried out in four main areas of West Greenland.

In the Disko-Nûgssuaq-Upernivik region a mapping programme on the Late Phanerozoic sediments and volcanics was continued.

In southern West Greenland, detailed mapping in the Archaean basement was continued in three regions; on rocks of the Godthåb district, in the Buksefjorden area, south of Godthåb and in the Fiskenæsset area farther to the south. The last named group with 14 geologists was the largest in the field in 1973.

\footnotetext{
* On July 23rd the Turbo Hawk Commander crashed shortly after take-off from Mesters Vig airport with the tragic loss of life of the pilot, Torbjörn Hamrö of Ehrenström Flyg and the photographer from the Geodetic Institute, Copenhagen, Svend Galtt; a third person in the aircraft miraculously escaped.
} 
(b) Specialised mapping projects were carried out on the Tertiary sediments and basalts of Nûgssuaq, on the Archaean complex of the Godthab district and on the alkaline rocks in the southern part of the Ilímaussaq intrusion in South Greenland.

(c) Quaternary investigations were concentrated between Frederikshåbs Isblink and Ameralik fjord in the Godthåb district while a study of the distribution and composition of the Recent sediments in the fjords and lakes was undertaken in the Fiskenæsset region.

(d) The seismic survey started in central West Greenland in 1969 was continued on Nûgssuaq and Svartenhuk Halvø.

In East Greenland an airborne gamma-spectrometric and magnetic survey was conducted between $72^{\circ}$ and $76^{\circ} \mathrm{N}$, supported by ground radiometric work.

(e) A programme was embarked upon in the Ilímaussaq area of South Greenland to study the geochemistry of river water. Samples were also collected by other geological teams in both West and East Greenland with a view to determining the heavy mineral content of the water.

(f) The Archaean basement complex of the Godthåb district, which has yielded the oldest terrestrial age dates known, continues to attract interest. Two age dating groups visited the area for the specific purpose of collecting samples for detailed isotopic studies. A reconnaissance and sampling programme was also undertaken on the nearby iron-bearing supracrustal rocks at Isua.

An experimental cartographical programme was carried out by one group attached to geological mapping teams in Disko, Nûgssuaq and Ubekendt Ejland as part of an attempt to improve the topographical map coverage in parts of Greenland.

In cooperation with the Geodetic Institute, Copenhagen, a programme of air photography was undertaken in East Greenland, north of Mesters Vig. Prior to the accident involving the chartered aircraft the region between $72^{\circ}$ and $74^{\circ} 30^{\prime} \mathrm{N}$ had been completed together with single routes further north.

Ground temperature measurements were recorded throughout the year at the stations set up previously at Holsteinsborg, Søndre Strømfjord, Jakobshavn and Godhavn.

Tertiary basalts and intrusives were sampled for detailed geochemical and petrological analysis on Nûgssuaq and Ubekendt Ejland.

(g) During all field activities economic assessment of the terrain is an important part of the Survey's work, and any mineralisations and deposits of economic potential are noted.

Sedimentological investigations having a bearing on the hydrocarbon potential of the West Greenland basin were carried out on Nûgssuaq, Upernivik $\emptyset$, Qeqertarssuaq, Itsako and Svartenhuk Halv $\emptyset$, and geophysical and geochemical activities mentioned under (d) and (e) were also related to economic assessment. 


\section{Collaboration with other institutes}

By employing summer contract geologists, geophysicists and other personnel, both Danish and foreign, the Survey enjoys fruitful collaboration with many scientific institutes. The material collected under GGU auspices forms the basis of numerous research projects. Contact is encouraged and maintained with other institutions interested in Greenland so that maximum benefit can be obtained from the sharing of resources and exchange of ideas.

In Denmark close cooperation with the Mineralogical Museum and the Mineralogical-Geological Institutes of the University of Copenhagen, the Danish Atomic Energy Commission, and the Technical University of Denmark in Copenhagen, has continued and the sharing of laboratory equipment and personnel with the University of Copenhagen has proved most beneficial.

In 1973 the Survey's staff was joined in the field by scientists from these Danish institutions and from the universities of Dundee, Edinburgh, Exeter, Heidelberg, Liverpool, London, Makerere, Manchester, Oxford, St. Andrews, Utrecht, from the University College of Wales at Aberystwyth, the Central Geological Survey in Prague, Kingston Polytechnic and Portsmouth Polytechnic.

While the Survey's capacity for geochemical work was markedly increased during 1973, collaboration with the universities of Birmingham and Leeds has also helped meet the demand for chemical data. Likewise the universities of Alberta, Copenhagen, Leeds, Oxford and Sheffield, as well as the Scottish Research Reactor Centre at East Kilbride and the Eidg. Technische Hochschule in Zürich, have provided isotopic age determinations on Survey rock material. Age dates on shell and wood have been dated through cooperation with the National Museum in Copenhagen and Isotopes Inc., New Jersey.

Throughout the year Survey personnel continued to contribute to international conferences and symposia and meetings were attended at Aachen, Amhurst-Massachusetts, Boulder, Brighton, Cambridge, Columbus, Düsseldorf, Firenze, Geneva, Haarlem, Hamilton, Hannover, Houston, Leeds, Lillehammer, London, LondonOntario, Narssarssuaq-Greenland, Montreal, Nice, Oslo, Ottawa, Sandefjord-Norway, Seattle, Sunbury-on-Thames, Toronto, Trondheim, Varangerhalvøja-Norway and Washington D.C.

During the year three members of the Survey took up temporary posts as guest professors at the universities of Geneva, Ohio and Ontario.

\section{Publications}

In 1973 compilation continued on the 1:100 000 and 1:500 000 bedrock map series and on the 1:500 000 Quaternary map series. Of these, two 1:100000 map sheets were published, Narssarssuaq 61 V 3 Nord and Nanortalik $60 \mathrm{~V} 1$ Syd. Two others, Midternæs $61 \mathrm{~V} 2$ Nord and Agatdal $70 \mathrm{~V} 1$ Nord were under completion in the drawing office, while four sheets, Charcot Land $71 \emptyset 4$ Nord, 


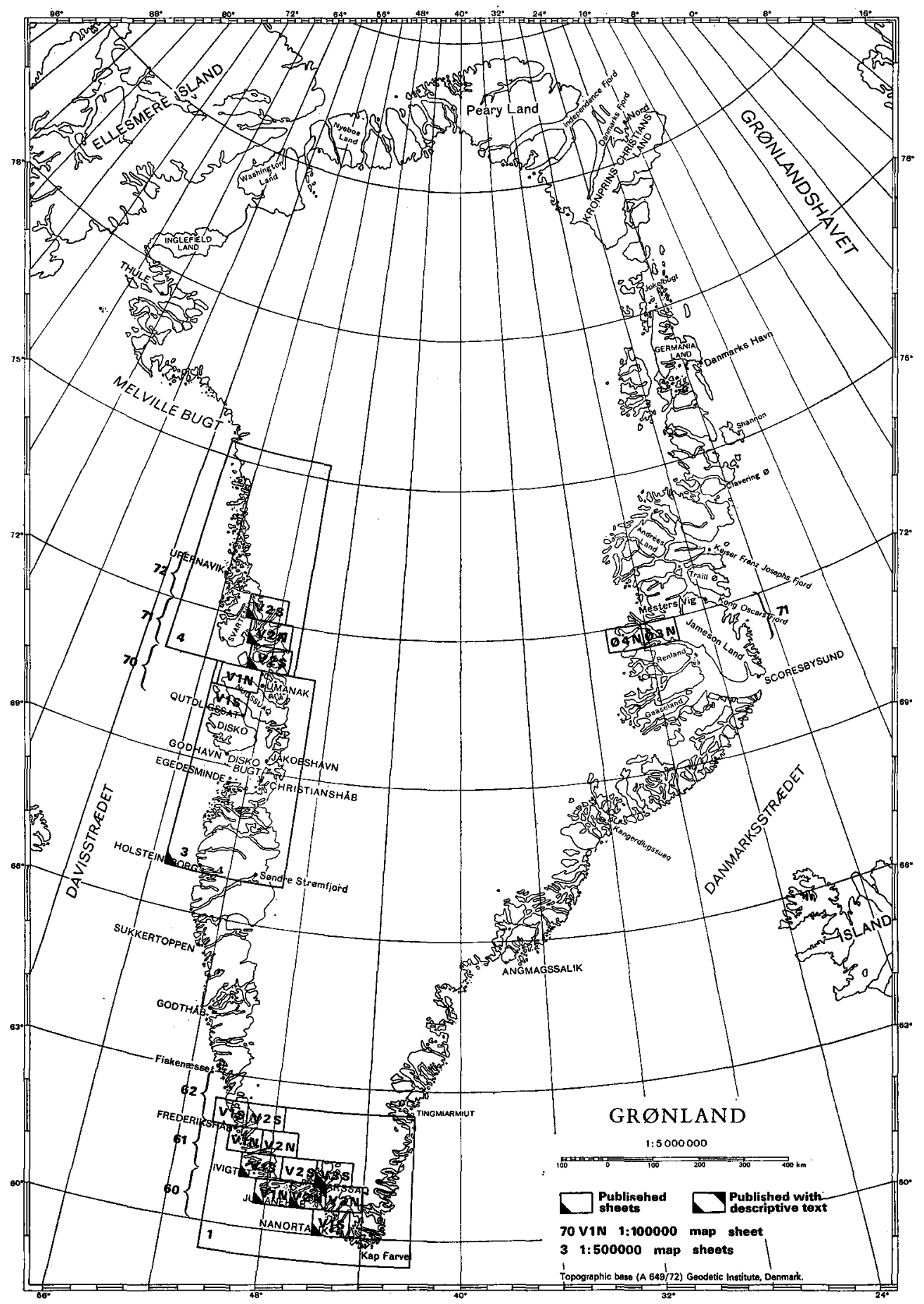

Fig. 2. Greenland showing coverage of Survey map sheets already issued and those under compilation. 
Neria $61 \mathrm{~V} 1$ Nord, Nerutussoq 62 V 1 Syd and Nigerdlikasik 62 V 2 Syd have been finished in manuscript form. The 1:500 000 bedrock sheet, Sydgrønland, was also finished in manuscript form while the 1:500 000 Quaternary map sheet S $\varnothing$ ndre Str $\varnothing \mathrm{mfjord}$ reached the final drawing-office stage.

Detailed maps of selected areas at various scales continued to form an important part of the Survey's publications and these were issued as illustrations accompanying written publications. Bulletins 104 to 107 (published in association with Meddelelser om Grønland), Reports 50 to 59, and Miscellaneous Papers 104 to 118 (reprinted from international journals) were all released in 1973.

The explanatory text to the 1:100 000 map sheet Julianehåb $60 \mathrm{~V} 2$ Nord, the first number of a new series, was published in association with Meddelelser om Grønland.

GGU publications were in 1973 sent out to 340 scientific institutions, mainly on an exchange basis.

\section{Mining and exploration}

By the end of 1973, 35 companies or groups of companies held prospection licences from the Ministry for Greenland. This is a sharp decrease in the number of valid concessions from the previous year. This trend should not be seen as a decline in overall interest in the economic potential of Greenland's bedrock but rather as a lull in activity following the expiry of a number of exploration concessions, with companies understandably waiting to see the outcome of the Ministry for Greenland's attempt to lay down final regulations governing oil and gas concessions.

In 1973 exclusive rights in respect of minerals were held by 24 companies, and under one of these the lead-zinc mine at Mârmorilik on the west coast began production in 1973.

Geological and geophysical data received from companies actively working in Greenland were interpreted by the Survey and by arrangement with consultants. Survey members have assisted companies holding concession rights with maps and other basic information as and when requested. The Survey's report archives containing results and notes of field work undertaken by the Survey since 1946 are available to companies for reference at the Survey's offices in Copenhagen. Over 40 reports were added to the archives during 1973.

A review of the economic potential of Greenland, issued as GGU Report 56 "A survey of the economic geology of Greenland (excluding fossil fuels)" has been well requested. In cooperation with the Danish Atomic Energy Commission's Research Establishment at Ris $\varnothing$, laboratory work continued on the evaluation of the radioactive mineral potential of the Ilimaussaq alkaline instrusion in South Greenland. In East Greenland airborne gamma-spectrometry with equipment constructed at Ris $\varnothing$, was carried out with a view to evaluate the mineral potential of the region between $72^{\circ}$ and $76^{\circ} \mathrm{N}$. 
Note

The following 20 articles report the Survey's principal field activities in Greenland in 1973 together with some laboratory investigations. Articles dealing with North Greenland and central West Greenland come first, followed by those from southern West Greenland, South Greenland and East Greenland.

The main results of isotopic age determination work carried out on Survey material during 1973, will be published in a sequel report (Report 66).

Unless otherwise stated at the end of each article, the author's address is the Survey's headquarters in Copenhagen.

\title{
LATE SILURIAN AND EARLY DEVONIAN GRAPTOLITES FROM NORTH GREENLAND
}

\author{
William B. N. Berry, Arthur J. Boucot, Peter R. Dawes and John S. Peel
}

The precise age of the youngest part of the geosynclinal fill of the North Greenland fold belt has been the subject of important discussion, particularly with regard to the problem of dating the Palaeozoic diastrophism (Kerr, 1967; Dawes, 1971). Since Lauge Koch's field work between 1916 and 1923 it has been known that strata bearing Monograptus priodon were involved in the folding (Koch, 1920), indicating the presence of Silurian of Llandovery-Wenlock age. In addition, Poulsen (1934) identified Cyrtograptus cf. C. multiramus and Monograptus bohemicus in collections made by Koch from unfolded shales on the platform, to the south of the fold belt, which demonstrated that the section included Wenlock and early Ludlow strata.

Preliminary examination of fossil material collected from both the platform and the fold belt in the Hall Land - Wulff Land region, during Operation Grant Land 1965-66, provided little new information on the age of the upper part of the succession (Dawes, 1971). However, a recent study of graptolites in these collections (W.B.N.B.) has revealed the presence in the fold belt of strata of Ludlow, Pridoli and earliest Devonian ages. Ludlow graptolites are also recorded from central Nyeboe Land, confirming the earlier platform record of Poulsen (1934).

Current examination of brachiopods in several faunas of 'shelly' fossils from the platform strata of Hall Land and Nyeboe Land also suggests the presence of Silurian strata as young as Ludlow (A.J.B.).

\section{Localities and fauna}

Collections from three localities are discussed. 